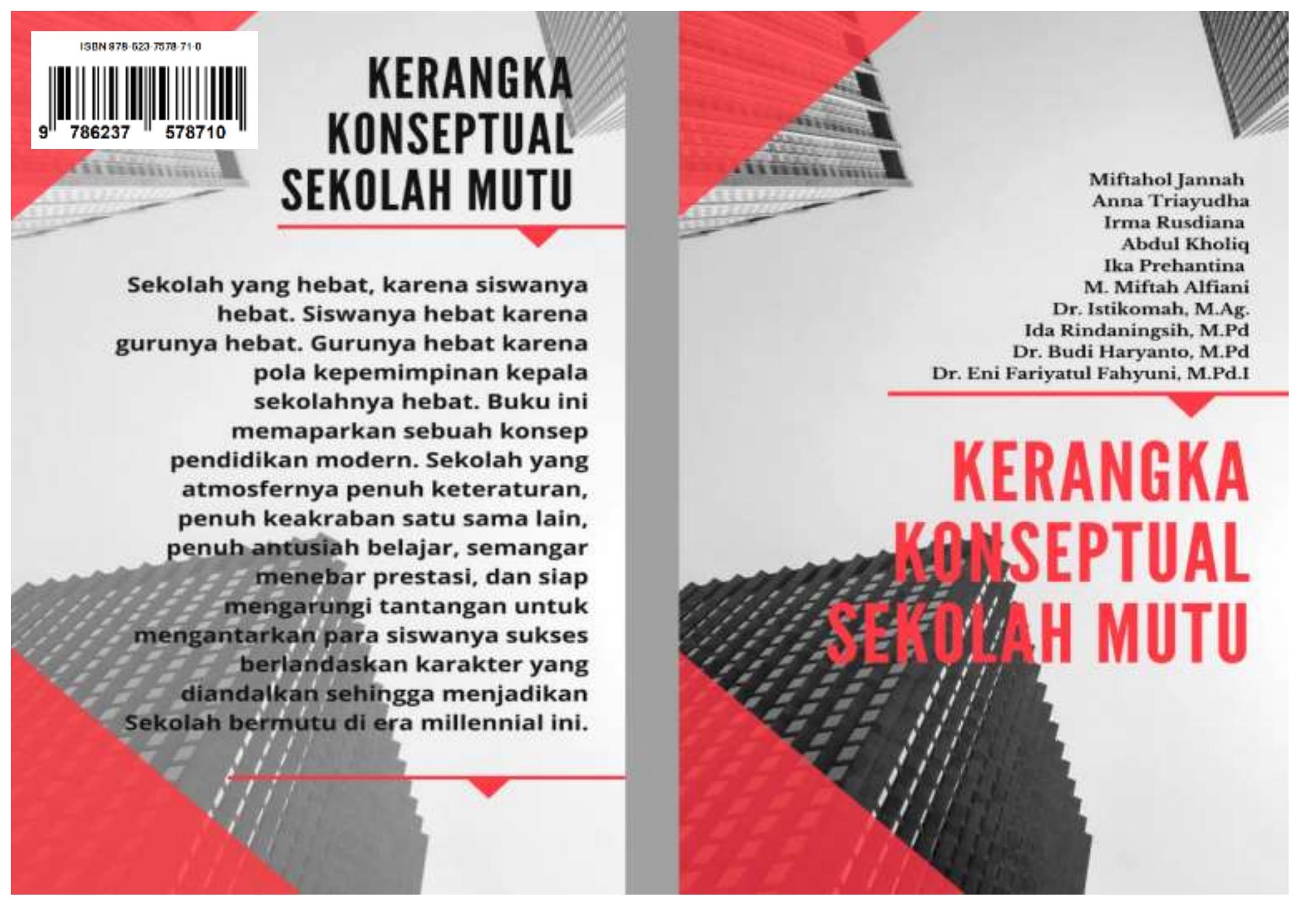





\title{
Buku Ajar Kerangka Konseptual Sekolah Mutu
}

\author{
Penulis: \\ Miftahol Jannah \\ Anna Triayudha \\ Irma Rusdiana \\ Abdul Kholiq \\ Ika Prihantina \\ M.Miftah Alfiani \\ Dr. Istikomah, M.Ag. \\ Ida Rindaningsih, M.Pd \\ Dr. Budi Haryanto, M.Pd
}

Dr. Eni Fariyatul Fahyuni, M.Pd.I

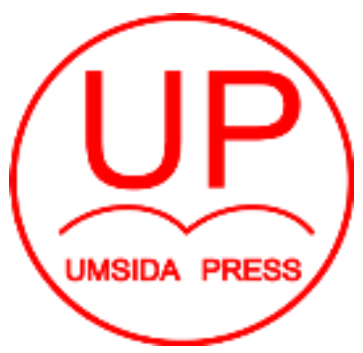

Diterbitkan oleh UMSIDA PRESS

JI. Mojopahit 666 B Sidoarjo

ISBN: 978-623-7578-71-0

Copyright@2020.

Authors

All rights reserved 


\section{Buku Ajar}

Kerangka Konseptual Sekolah Mutu

\section{Penulis :}

Miftahol Jannah

Anna Triayudha

Irma Rusdiana

Abdul Kholiq

Ika Prihantina

M.Miftah Alfiani

Dr. Istikomah, M.Ag.

Ida Rindaningsih, M.Pd

Dr. Budi Haryanto, M.Pd

Dr. Eni Fariyatul Fahyuni, M.Pd.I

ISBN : 978-623-7578-71-0

\section{Editor :}

Dr. Eni Fariyatul Fahyuni, M.Pd.I

Dr. Septi Budi Sartika. M.Pd

\section{Copy Editor :}

Dr. Eni Fariyatul Fahyuni, M.Pd.I

Design Sampul dan Tata Letak :

Dinda Nurrahma A.F.M., S.E.

Penerbit :

UMSIDA Press

\section{Redaksi :}

Universitas Muhammadiyah Sidoarjo

J1. Mojopahit No 666B

Sidoarjo, Jawa TImur

Cetakan pertama, Agustus 2020

(C) Hak cipta dilindungi undang-undang

Dilarang memperbanyak karya tulis ini dengan suatu apapun tanpa ijin tertulis dari penerbit. 


\section{KATA PENGANTAR}

Puji syukur kepada Tuhan Yang Maha Esa, sehingga Buku Ajar Kerangka Konseptual Sekolah Mutu ini dapat disusun dengan baik meskipun perlu penyempurnaan lebih lanjut. Kerangka Konseptual Sekolah Mutu ini dikhususkan untuk pegangan Mahasiswa Magister Manajemen Pendidikan Islam Universitas Muhammadiyah Sidoarjo.

Kerangka Konseptual Sekolah Mutu menentukan sukses dan kelancaran progam pendidikan serta merupakan bagian yang tak terpisahkan dalam manajemen pengelolaan pendidikan. Dengan selesainya penulisan buku ajar ini penulis mengucapkan terima kasih kepada semua pihak yang telah memberikan bahan-bahan tulisan baik langsung maupun tidak langsung. Penulis juga mengucapkan terima kasih khususnya kepada:

1. Dr. Hidayatullah, M.Si pemangku pimpinan tertinggi yaitu Rektor Universitas Muhammadiyah Sidoarjo yang telah memberikan dan memfasilitasi dalam penulisan buku ajar ini. 
2. LP3iK Universitas Muhammadiyah Sidoarjo yang telah memfasilitasi dan mengkoordinasi dalam penulisan buku ajar ini.

3. Dr. Istikomah, M.Ag. sebagai Dekan Fakultas Agama Islam, Universitas Universitas Muhammadiyah Sidoarjo yang telah memberikan dukungan penulisan buku ajar ini.

4. Dr. Budi Haryanto, M.Pd. sebagai Kepala Program Studi Magister Manajemen Pendidikan Islam, Universitas Universitas Muhammadiyah Sidoarjo yang memberikan dukungan untuk mengikuti penulisan buku ajar ini.

5. Para narasumber, dosen serta teman-teman mahasiswa program studi Magister Manajemen Pendidikan Islam, Universitas Universitas Muhammadiyah Sidoarjo yang telah banyak membantu atas penyusunan penulisan buku ajar ini. Akhir kata, kritik dan saran sangat diharapkan untuk penyempurnaan buku ajar ini. Harapan kami semoga buku ajar ini dapat digunakan sebagai tambahan informasi dan bermanfaat bagi aktivitas pembelajaran di Program Studi Magister Manajemen Pendidikan Islam, Fakultas Agama Islam, Universitas Universitas Muhammadiyah Sidoarjo.

Penulis 


\section{DAFTAR ISI}

KERANGKA KONSEPTUAL SEKOLAH MUTU

I. Manajemen Pendidikan Islam
A. Pengertian Manajemen
B. Unsur-unsur Manajemen Pendidikan
C. Fungsi Managemen

II. PERAN MASYARAKAT DALAM PENDIDIKAN ISLAM
A. Pengertian Masyarakat
25
B. Peran masyarakat dalam Manajemen Pendidikan Islam
27

III. MENCETAK GENERASI ISLAMI
A. Mendidik Generasi Aqil Baligh
36
B. UJrgensi Pengembangan Religius Culture di
Sekolah
39
C. Anak Curag Salah Gurukah
47
D. UNBK jujur dan Berintegritas
51

DAFTAR PUSTAKA

LAMPIRAN 


\section{Bab I \\ Manajemen Pendidikan Islam}

A. Pengertian Manajemen

Secara umum aktivitas manajemen dalam organisasi diarahkan untuk mencapai tujuan organisasi secara efektif dan efisien. Manajemen adalah proses bekerja sama antara individu dan kelompok serta sumber daya lainnya dalam mencapai tujuan, organisasi adalah sebagai aktivitas manajemen. Dengan kata lain, aktivitas manajerial hanya ditemukan dalam wadah sebuah organisasi, baik organisasi bisnis, sekolah dan juga lainnya. ${ }^{1}$

Setiap ahli memberikan pandangan yang berbeda tentang batasan manajemen, karena itu tidak mudah memberikan arti universal yang dapat diterima semua orang. Namun demikian dari pikiran-pikiran semua ahli tentang definisi manajemen kebanyakan menyatakan bahwa manajemen merupakan suatu proses tertentu yang menggunakan kemampuan atau keahlian untuk mencapai suatu tujuan yang didalam pelaksanaannya dapat mengikuti alur keilmuan secara ilmiah dan dapat pula menonjolkan kekhasan atau gaya manajer dalam mendayagunakan kemampuan orang lain. ${ }^{2}$ Istilah manajemen sudah populer dalam kehidupan organisasi. Dalam makna yang sederhana "management" diartikan sebagai pengelolaan.

1 Syafaruddin, Manajemen Lembaga Pendidikan Islam (Jakarta: Ciputat Press, 2005), h. 41.

2 Tim Dosen Administrasi Pendidikan UI, Manajemen Pendidikan (Bandung: Al- Fabeta, 2009), h. 86. 
Suatu proses menata atau mengelola organisasi dalam mencapai tujuan yang diinginkan dipahami sebagai manajemen. ${ }^{3}$ Tegasnya, kegiatan manajemen selalu saja melibatkan alokasi dan pengawasan uang, sumberdaya manusia, dan fisik untuk mencapai tujuan yang ditetapkan. Sebagai ilmu, manajemen memiliki pendekatan sistematik yang selalu digunakan dalam memecahkan masalah. Pendekatan manajemen bertujuan untuk menganalisis proses, membangun kerangka konseptual kerja, mengidentifikasi prinsip-prinsip yang mendasarinya dan membangun teori manajemen dengan menggunakan pendekatan tersebut. Karena itu, manajemen adalah proses universal berkenaan dengan adanya jenis lembaga, berbagai posisi dalam lembaga, atau pengalaman pada lingkungan yang beragam luasnya antara berbagai persoalan kehidupan.

Berdasarkan penegasan di atas, maka manajemen berisikan unsur: struktur organisasi yang tertata, terarah kepada tujuan dan sasaran, dilakukan melalui usaha orang-orang, dan menggunakan sistem dan prosedur. Manajemen adalah suatu proses pengaturan dan pemanfaatan sumber daya yang dimiliki organisasi melalui kerjasama para anggota untuk mencapai tujuan organisasi.

Manajemen merupakan perilaku anggota dalam suatu organisasi untuk mencapai tujuannya. Sementara itu George R. Tarry seperti yang dikutip Syafaruddin menjelaskan bahwa manajemen adalah kemampuan mengarahkan dan mencapai hasil yang

3 Syafaruddin \& Nurmawati, Pengelolaan Pendidikan Mengembangkan Keterampilan Manajemen Pendidikan Menuju Sekolah Efektif (Medan: perdana Publishing, 2011), h. 16. 
diinginkan dengan tujuan dari usaha-usaha manusia dan sumber daya lainnya. ${ }^{4}$ Manajemen dalam Kamus Besar Bahasa Indonesia, diartikan proses penggunaan sumber daya secara efektif untuk mencapai sasaran. ${ }^{5}$ Dalam istilah manajemen terdapat tiga pandangan yang berbeda, pertama: Mengartikan administrasi lebih luas dari pada manajemen (manajemen merupakan inti dari administrasi), kedua: melihat manajemen lebih luas dari administrasi dan ketiga: pandangan yang beranggapan bahwa manajemen identik dengan administrasi. ${ }^{6}$

Makna manajemen sering diartikan sebagai ilmu, kiat dan professional. Manajemen diartikan sebagai ilmu karena merupakan suatu bidang ilmu pengetahuan yang secara sistematik berusaha memahami mengapa dan bagaimana orang bekerja sama. Manajemen diartikan sebagai kiat karena manajemen mencapai sasaran melalui cara-cara dengan mengatur orang lain menjalankan tugasnya.

Sedangkan manajemen diartikan sebagai profesi karena manajemen dilandasi oleh keahlian khusus untuk mencapai suatu prestasi manajer, dan para professional dituntut oleh suatu kode etik.8 Untuk memahami istilah manajemen, pendekatan yang digunakan adalah berdasarkan pengalaman manajer. Manajemen sebagai suatu sistem yang setiap komponennya menampilkan

4 Syafaruddin, Mnaajemen Lembaga Pendidikan......, h. 41.

5 Lukman Ali, dkk., Kamus Besar Bahasa Indonesia, Cet II (Jakarta: Balai Pustaka, 1997), h. 623.

6 E. Mulyasa, Manajemen Berbasis Sekolah, Cet I (Bandung: PT. Remaja Rasindo, 2002), h. 19. 
sesuatu untuk memenuhi kebutuhan. Dengan demikian maka manajemen merupakan suatu proses untuk mencapai tujuan organisasi secara efektif dan efisien. Pencapaian tujuantujuan organisasi dilaksanakan dengan pengelolaan fungsi-fungsi perencanaan (planning), pengorganisasian (organizing), penyusunan personalia atau kepegawaian (staffing), pengarahan dan kepemimpinan (leading) dan pengawasan (controlling). ${ }^{7}$

Ada bermacam-macam definisi tentang manajemen, dan tergantung dari sudut pandang, keyakinan, dan komprehensip dari para pendefinisi, diantara lain: kekuatan menjalankan sebuah perusahaan dan bertanggung jawab atas kesuksesan atau kegagalannya. Ada pula pihak lain yang berpendapat bahwa, manajemen adalah tindakan memikirkan dan mencapai hasil-hasil yang diinginkan melalui usaha-usaha kelompok yang terdiri dari tindakan mendayagunakan bakat-bakat manusia dan sumber daya manusia secara singkat orang pernah menyatakan tindakan manajemen adalah sebagai tindakan merencanakan dan mengimplementasikan. ${ }^{8}$

Manajemen adalah ilmu dan seni mengatur proses pemanfaatan sumber daya manusia dan sumber-sumber lain secara efektif dan efisien untuk mencapai suatu tujuan. Manajemen merupakan sebuah proses kerja sama untuk mencapai tujuan bersama. Sementara Thoha, berpendapat bahwa manajemen

7 Nanang Fattah, Landasan Manajemen Pendidikan, Cet I (Bandung: PT. Remaja Rosda Karya, 1999), h. 1

8 Miftah Thoha, Kepemimpinan Dalam Manajemen, Cet II (Jakarta: Raja Grafindo Persada, 1995), h. 8. 
diartikan sebagai "suatu proses pencapaian tujuan organisasi lewat usaha orang lain". ${ }^{9}$

Sedangkan Nawawi menyatakan, yaitu: "manajemen adalah kegiatan yang memerlukan kerja sama orang lain untuk mencapai tujuan"12 Pendapat kedua pakar di atas, dapat disimpulkan, bahwa manajemen merupakan proses kerja sama antara dua orang atau lebih untuk mencapai tujuan bersama. Lebih lanjut, pengertian manajemen dinyatakan oleh Martayo, ia menyatakan bahwa "manajemen adalah usaha untuk menentukan, menginterpretasikan dan mencapai tujuan-tujuan organisasi dengan pelaksanaan fungsifungsi perencanaan, pengorganisasian, penyusunan personalia atau kepegawaian, pengarahan dan kepemimpinan serta pengawasan. ${ }^{10}$ Menurut Terry, yang dikutip Anoraga, menyatakan bahwa manajemen merupakan proses yang khas yang terdiri dari tindakantindakan perencanaan, pengorganisasian, pelaksanaan dan pengawasan yang masing-masing bidang tersebut digunakan baik ilmu pengetahuan maupun keahlian dan yang diikuti secara berurutan dalam rangka usaha mencapai sasaran yang telah ditetapkan. ${ }^{11}$ Manajemen merupakan sebuah proses kerja sama untuk mencapai tujuan bersama. Dengan demikian yang dimaksud dengan manajemen, ialah prosespencapaian tujuan organisasi melalui pengaturan orang-orang lain untuk melaksanakan berbagai

9 Miftah Thoha, Kepemimpinan Dalam Manajemen, Cet II (Jakarta: Raja Grafindo Persada, 1995), h. 8.

10 Susilo Martoyo, Manajemen Sumber Daya Manusia, Cet IV (Yogyakarta: BPPFE, 1980), h. 3

11 Hadari Nawawi, Administrasi Pendidikan, Cet V (Jakarta: Jahi Masagung, 1993), h. 13. 
pekerjaan yang diperlukan. Dengan demikian manajemen merupakan kemampuan dan keterampilan khusus yang dimiliki oleh seseorang untuk melakukan suatu kegiatan baik secara perorangan maupun secara bersamasama atau melalui orang lain dalam upaya mencapai tujuan organisasi secara produktif, efektif dan efisien.

Dalam prespektif lebih luas, manajemen adalah suatu proses pengaturan dan pemanfaatan sumber daya yang dimiliki organisasi melalui kerjasama para anggota untuk mencapai tujuan organisasi secara efektif dan efisien. Berarti manajemen merupakan prilaku anggota dalam suatu organisasi untuk mencapai tujuannya. Dengan kata lain, organisasi adalah wadah bagi operasionalisasi manajemen, karena itu di dalamnya ada sejumlah unsur yang membentuk kegiatan manajemen, yaitu: unsur manusia, barang-barang, mesin, metode, uang dan pasar. Terdapat tiga fokus untuk mengartikan manajemen yaitu:

1. Manajemen sebagai suatu kemampuan atau keahlian yang selanjutnya menjadi cikal bakal manajemen sebagai suatu profesi. Manajemen sebagai suatu ilmu menekankan perhatian pada keterampilan dan kemampuan manajerial yang diklasifikasikan menjadi kemampuan / keterampilan teknikal, manusiawi dan konseptual.

2. Manajemen sebagai proses yaitu dengan menentukan langkah yang sistematis dan terpadu sebagai aktivitas manajemen. 
3. Manajemen sebagai seni tercermin dari perbedaan gaya (style) seseorang dalam menggunakan atau memberdayakan orang lain untuk mencapai tujuan. ${ }^{12}$

Prinsip manajemen berdasarkan informasi; banyak aktivitas manajemen yang membutuhkan data dan informasi secara cepat, lengkap, dan akurat. Suatu aktivitas pengambilan keputusan sangat didukung oleh informasi begitupun untuk melaksanakan kegiatan rutin dan incidental diperlukan informasi yang telah dirancang sedemikian rupa sehingga memudahkan manajer dan pengguna mengakses dan mengolah informasi. Kehadiran manajemen dalam organisasi adalah untuk melaksanakan kegiatan agar suatu tujuan tercapai dengan efektif dan efisien. Secara tegas tidak ada rumusan yang sama dan berlaku umum untuk fungsi manajemen. Namun demikian, fungsi manajemen dapat ditelaah dari aktifitas-aktifitas utama yang dilakukan para manajer yaitu perencanaan, pelaksanaan, dan penilaian.

Dilakukannya manajemen agar pelaksanaan suatu usaha terencana secara sistematis dan dapat dievaluasi secara benar, akurat dan lengkap sehingga mencapai tujuan secara produktif, berkualitas, efektif dan efisien. Produktivitas; adalah perbandingan terbaik antara hasil yang diperoleh (out put) dengan jumlah sumber yang dipergunakan (input). Produktivitas dapat dinyatakan secara kuantitas maupun kualitas. Kuantitas aut put berupa jumlah tamatan dan kuantitas in put berupa jumlah tenaga kerja dan sumber daya selebihnya. Kualitas menunjukan kepada suatu ukuran penilaian atau

12 Tim Dosen Administrasi Pendidikan UI, Manajemen...,h. 86. 
penghargaan yang diberikan atau dikenakan kepada barang (products) dan/jasa (services) tertentu berdasarkan timbangan objek atas bobot dan/atau kinerja.

\section{B. Unsur-unsur Manajemen}

Untuk mencapai tujuan yang telah ditetapkan, seorang manajer membutuhkan sarana manajemen yang disebut dengan unsur manajemen. Menurut pendapat yang dikemukakan oleh Manullang sebagaimana dikutip oleh Mastini tentang unsur manajemen tersebut, terdiri atas manusia, material, mesin, metode, money dan markets, setiap unsur-unsur tersebut memiliki penjelasan dan peranan bagi suatu memanajemen agar untuk mengetahui bahwa manajemen memiliki unsur-unsur perlu dimanfaatkan unsurunsur manajemen tersebut. Untuk mengetahui hal tersebut dapat dijelaskan unsur-unsur manajemen seperti di bawah ini.

1. Manusia (Man). sarana penting atau sarana utama setiap manajer untuk mencapai tujuan yang telah ditentukan oleh individu-individu tersendiri atau manusianya. Berbagai kegaitan-kegiatan yang dapat diperbuat dalam mencapai tujuan seperti yang dapat ditinjau dari sudut pandang proses, perencanaan, pengorganisasian, staffing, pengarahan, dan pengawasan atau dapat pula kita tinjau dari sudut bidang, seperti penjualan, produksi, keuangan dan personalia. Man atau manusia ataupun juga sering diistilahkan dengan sumber daya manusia dalam dunia manajemen merupakan faktor yang sangat penting dan menentukan. Manusia yang merancang tujuan, menetapkan tujuan dan manusia jugalah yang nantinya 
akan menjalankan proses dalam mencapai tujuan yang ditetapkan tersebut.13

2. Material (Material). Dalam proses pelaksanaan kegiatan, manusia menggunakan matrial atau bahan-bahan. Oleh karna itu, material dianggap pula sebagaialat atau sarana manajemen untuk mencapai tujuan.

3. Mesin (Machine). Dalam kemajuan teknologi, manusia bukan lagi sebagai pembantu mesin seperti pada masa lalu sebelum Revolusi Industri terjadi. Bahkan, sebaliknya mesin telah berubah kedudukannya menjadi pembantu manusia.

4. Metode (Method). Untuk melakukan kegiatan secara guna dan berhasil guna, manusia dihadapkan kepada berbagai alternatif metode cara menjalankan pekerjaan tersebut sehingga cara yang dilakukannya dapat menjadi sarana atau alat manajemen untuk mencapai tujuan.

5. Uang (Money). Uang sebagai sarana manajemen harus digunakan sedimikian rupa agar tujuan yang diinginkan tercapai. Kegiatan atau ketidaklancaran proses manajemen sedikit banyak dipengruhi oleh pengelolaan.

6. Pasar (Markets). Bagi badan yang bergerak dibidang industri maka sarana manajemens penting lainnya seperti pasar-pasar atau market. Untuk mengetahui bahwa pasar bagi hasil produksi.jelas tujuan perusahaan industri tidak mustahil semua itu dapat diurai sebagian dari masalah utama dalam perusahaan industri adalah minimal mempertahankan pasar yang sudah

13 Agustini, Pengelolaan dan Unsur-unsur Manajemen (Jakarta: Citra Pustaka, 2013), h. 61. 
ada. Jika mungkin, mencari pasar baru untuk hasil produksinya. Oleh karena itu. Market merupakan salah satu sarana manajemen penting lainnya. baik bagi perusahaan industri maupun bagi semua badan yang bertujuan untuk mencari laba. Dari beberapa unsur-unsur manajemen di atas dapat disimpulkan, bahwa manusia adalah unsur dan sarana utama untuk mencapai tujuan yang telah ditentukan. Berbagai kegiatan yang dapat diperbuat dalam mencapai tujuan seperti dari sudut pandang proses, perencanaan, pengorganisasian, staffing, pengarahan, dan pengawasan hanya dapat dilakukan oleh manusia ataupun juga sering diistilahkan dengan sumber daya manusia dalam dunia manajemen merupakan faktor yang sangat penting dan menentukan.

C. Fungsi-fungsi Manajemen

Sifat dasar manajemen adalah sangat beragam, karena mencakup banyak dimensi aktivitas dan lembaga. Manajemen berhubungan dengan semua aktivitas organisasi dan dilaksanakan pada semua level organisasi. Karena itu manajemen bukan merupakan sesuatu yang terpisah atau pengurangan fungsi suatu organisasi tidak hanya memiliki mengelola satu bidang tetapi juga sangat luas sebagai contoh: bidang produksi, pemasaran, keuangan atau personil. Dalam hal ini manajemen suatu proses umum terhadap semua fungsi lain yang dilaksanakan dalam organisasi. Tegasnya manajemen adalah suatu perpaduan aktivitas.

Aktivitas manajemen mencakup spektrum yang sangat luas, sebab dimulai dari bagaimana menentukan arah organisasi 
di masa depan, sampai mengawasi kegiatan untuk mencapai tujuan. Maka dalam rangka mencapai tujuan organisasi secara efektif dan efisien manajemen harus difungsikan sepenuhnya pada setiap organisasi. Adapun fungsi-fungsi manajemen dapat dijelaskan sebagai berikut:

1) Perencanaan

Perencanaan merupakan salah satu hal yang penting yang perlu dibuat untuk setiap usaha dalam rangka mencapai suatu tujuan. Karena seringkali pelaksanaan suatu kegiatan akan mengalami suatu kesulitan dalam mencapai tujuan tanpa adanya perencanaan ${ }^{14}$. Kesulitan tersebut dapat berupa penyimpangan arah dari pada tujuan, atau ada pemborosan modal yang mengakibatkan gagalnya semua kegiatan dalam mencapai suatu tujuan. Oleh karena itu perencanaan adalah penentuan secara matang dan cerdas tentang apa yang akan dikerjakan dimasa yang akan datang dalam rangka mencapai tujuan.

Menurut Aderson sebagaimana yang dikutif oleh Marno, mengatakan bahwa perencanaan adalah proses mempersiapkan seperangkat keputusan bagi perbuatan dimasa datang. ${ }^{15}$ Definisi ini mengisyaratkan bahwa pembuatan keputusan merupakan bagian dari perencanaan, namun proses

14 Syafaruddin \& Nurmawati, Pengelolaan Pendidikan: Mengembangkan Keterampilan Manajemen Pendidikan Menuju Sekolah Efektif, (Medan: Perdana Publishing, 2011), h. 51

15 Marno \& Trio Supriyanto, Manajemen dan Kepemimpinan Pendidikan Islam, (Bandung: P.T Refika Aditama, 2008), h. 13 
perencanaan dapat juga terpikir setelah tujuan dan keputusan diambil.

Perencanaan selalu terkait dengan masa depan, dan masa depan selalu tidak pasti, banyak faktor yang berubah dengan cepat. Tanpa perencanaan, sekolah atau lembaga pendidikan akan kehilangan kesempatan dan tidak dapat menjawab pertanyaan tentang apa yang akan dicapai, dan bagaimana mencapainya. Oleh karena itu rencana harus dibuat agar semua tindakan terarah dan terfokus pada tujuan yang hendak dicapai. Perencanaan dibuat harus berdasarkan beberapa sumber antara lain:

a) Kebijaksanaan pucuk pimpinan (Policy top management)

b) Hasil pengawasan, yaitu suatu perencanaan akan dibuat atas dasar faktafakta maupun data-data dari pada hasil pengawasan suatu kegiatan kerja, sehingga dengan demikian dibuatlah suatu perencanaan perbaikan maupun penyesuaian ataupun perombakan secara menyeluruh dari pada rencana yang telah pernah dilaksanakan.

c) Kebutuhan masa depan, yaitu suatu perencanaan sengaja dibuat untuk mempersiapkan masa depan yang baik ataupun untuk mencegah hambatanhambatan dari rintangan-rintangan guna mengatasi persoalan-persoalan yang akan timbul. ${ }^{16}$

16 Marno \& Trio Supriyanto, Manajemen dan Kepemimpinan Pendidikan Islam, (Bandung: P.T Refika Aditama, 2008), h. 13. 
d) Penemuan-penemuan baru, yaitu suatu perencanaan yang dibuat berdasarkan studi faktual ataupun yang terus menerus maka akan menemukan ide-ide ataupun pendapat baru, untuk suatu kegiatan kerja.

e) Prakarsa dari dalam, yaitu suatu planning yang dibuat akibat inisiatif atau usul-usul dari bawahan dari suatu kegiatan kerja sama, untuk mencapai suatu tujuan.

f) Prakarsa dari luar, yaitu suatu rencana yang dibuat akibat dari saran-saran ataupun kritik-kritik dari orang-orang di luar organisasi. Perencanaan merupakan tindakan awal dalam aktivitas manajerial pada setiap organisasi. Karena itu perencanaan akan menentukan adanya perbedaan kinerja suatu organisasi dengan organisasi lain dalam pelaksanaan rencana untuk mencapai tujuan.

Dalam proses perencanaan terhadap program pendidikan yang akan dilaksanakan, khususnya dalam lembaga pendidikan Islam, maka prinsip perencanaan harus mencerminkan terhadap nilai-nilai Islami yang bersumberkan pada al-Qur'an dan al-Hadits.

\section{2) Pengorganisasian (organizing)}

Organisasi adalah sistem kerja sama sekelompok orang untuk mencapai tujuan bersama. ${ }^{17}$ Langkah pertama dalam pengorganisasian diwujudkan melalui perencanaan dengan menetapkan bidang-bidang atau fungsi-fungsi yang termasuk ruang

17 Anwar Ibrahim, Memahami Paradigma Baru Pendidikan Nasional dalam UU Sisidiknas, (Jakarta: Depag RI, 2003), h. 37. 
lingkup kegiatan yang akan diselenggarakan oleh suatu kelompok kerjasama tertentu. Keseluruhan pembidangan itu sebagai suatu kesatuan merupakan total sistem yang bergerak kearah satu tujuan.

Dengan demikian, setiap pembidangan kerja dapat ditempatkan sebagai sub sistem yang mengemban sejumlah tugas yang sejenis sebagai bagian dari keseluruhan kegiatan yang diemban oleh kelompok-kelompok kerjasama tersebut. Wujud dari pelaksanaan organizing ini adalah tampaknya kesatuan yang utuh, kekompakan, kesetiakawanan dan terciptanya mekanisme yang sehat, sehingga kegiatan lancar, stabil dan mudah mencapai tujuan yang ditetapkan. Proses organizing yang menekankan pentingnnya tercipta kesatuan dalam segala tindakan, dalam hal ini al-Qur'an telah menyebutkan betapa pentingnya tindakan kesatuan yang utuh, murni dan bulat dalam suatu organisasi. Artinya:

"Dan berpeganglah kamu semuanya kepada tali (agama) Allah, dan janganlah kamu bercerai berai, dan ingatlah akan nikmat Allah kepadamu ketika kamu dahulu (masa Jahiliyah) bermusuhmusuhan, Maka Allah mempersatukan hatimu, lalu menjadilah kamu Karena nikmat Allah, orang-orang yang bersaudara; dan kamu Telah berada di tepi jurang neraka, lalu Allah menyelamatkan kamu dari padanya. Demikianlah Allah menerangkan ayat-ayat-Nya kepadamu, agar kamu mendapat petunjuk".

\section{3) Penggerakan (actuating)}

Fungsi actuating merupakan bagian dari proses kelompok atau organisasi yang tidak dapat dipisahkan. Adapun istilah yang dapat dikelompokkan ke dalam fungsi ini adalah directing commanding, leading dan coordinatin. Karena tindakan actuating sebagaimana 
tersebut di atas, maka proses ini juga memberikan motivating, untuk memberikan penggerakan dan kesadaran terhadap dasar dari pada pekerjaan yang mereka lakukan, yaitu menuju tujuan yang telah ditetapkan, disertai dengan memberi motivasi-motivasi baru, bimbingan atau pengarahan, sehingga mereka bisa menyadari dan timbul kemauan untuk bekerja dengan tekun dan baik.

Bimbingan menurut Hadari berarti memelihara, menjaga dan memajukan organisasi melalui setiap personal, baik secara struktural maupun fungsional, agar setiap kegiatannya tidak terlepas dari usaha mencapai tujuan. Al-Qur'an dalam hal ini telah memberikan pedoman dasar terhadap proses pembimbingan, pengarahan ataupun memberikan peringatan dalam bentuk actuating ini.

\section{4) Evaluasi/Controlling}

Evaluasi dalam manajemen pendidikan Islam ini mencakup dua kegiatan, yaitu penilaian dan pengukuran. Untuk dapat menentukan nilai dari sesuatu, maka dilakukan pengukuran dan wujud dari pengukuran itu adalah pengujian. Controlling itu penting sebab merupakan jembatan terakhir dalam rantai fungsional kegiatan-kegiatan manajemen. pengawasan merupakan salah satu cara para manajer untuk mengetahui apakah tujuan-tujuan organisasi itu tercapai atau tidak dan mengapa terpai atau tidak tercapai. Selain itu controlling adalah sebagai konsep pengendalan, pemantau efektifitas dari perencanaan, pengorganisasian, dan kepemimpinan serta pengambilan perbaikan pada saat dibutuhkan. 


\section{Bab III \\ Peran Masyarakat dalam Pendidikan Islam}

\section{A. Pengertian Masyarakat}

Secara etimologis kata "masyarakat" berasal dari bahasa Arab, yaitu "musyarak" yang artinya hubungan (interaksi). Sehingga definisi masyarakat adalah suatu kelompok manusia yang hidup bersama-sama di suatu tempat dan saling berinteraksi dalam komunitas yang teratur. Suatu masyarakat terbentuk karena setiap manusia menggunakan perasaan, pikiran, dan hasratnya untuk bereaksi terhadap lingkungannya. Hal tersebut menunjukkan bahwa manusia adalah mahluk sosial yang secara kodrati saling membutuhkan satu sama lainnya

B. Ciri-ciri Masyarakat

Suatu masyarakat dapat dikenali dari karakteristik yang ada di dalamnya. Adapun ciri-ciri masyarakat adalah sebagai berikut:

1. Berada di Wilayah Tertentu

Mengacu pada pengertian masyarakat di atas, suatu kelompok masyarakat mendiami di suatu wilayah tertentu secara bersama-sama dan memiliki suatu sistem yang mengatur hubungan antar individu.

2. Hidup Secara Berkelompok

Manusia adalah mahluk sosial dan akan selalu membentuk kelompok berdasarkan kebutuhan bersama. Kelompok manusia ini akan semakin besar dan berubah menjadi suatu masyarakat yang saling tergantung satu sama lain. 


\section{Terdapat Suatu Kebudayaan}

Suatu kebudayaan hanya dapat tercipta bila ada masyarakat. Oleh karena itu, sekelompok manusia yang telah hidup bersama dalam waktu tertentu akan melahirkan suatu kebudayaan yang selalu mengalami penyesuaian dan diwariskan secara turuntemurun.

4. Terjadi Perubahan

Suatu masyarakat akan mengalami perubahan dari waktu ke waktu karena memang pada dasarnya masyarakat memiliki sifat yang dinamis. Perubahan yang terjadi di masyarakat akan disesuaikan dengan kebudayaan yang sebelumnya telah ada.

5. Terdapat Interaksi Sosial

Interaksi sosial akan selalu terjadi di dalam suatu masyarakat. Interaksi ini bisa terjadi bila individu-individu saling bertemu satu dengan lainnya.

6. Terdapat Pemimpin

Aturan dan norma dibutuhkan dalam suatu masyarakat agar kehidupan harmonis dapat terwujud. Untuk itu, maka dibutuhkan pemimpin untuk menindaklanjuti hal-hal yang telah disepakati sehingga dapat berjalan sebagaimana mestinya

7. Terdapat Stratafikasi Sosial

Di dalam masyarakat akan terbentuk golongan tertentu, baik berdasarkan tugas dan tanggungjawab, maupun religiusitasnya. Dalam hal ini stratafikasi dilakukan dengan menempatkan individu pada posisi tertentu sesuai dengan keahlian dan kemampuannya. 
C. Peran Masyarakai Dalam Manajemen Pendidikan Islam

Peran serta masyarakat dalam pendidikan adalah aktivitas yang dilakukan oleh sekelompok orang dalam bidang pendidikan dengan tujuan untuk memajukan pendidikan dengan cara-cara tertentu. Kelompok orang yang dimaksud adalah dapat berupa masyarakat yang berhubungan langsung dengan pendidika seperti orang tua siswa yang tergabung dalam komite sekolah, masyarakat luas yang tergabung dalam dewan pendidikan, dunia usaha seperti badan-badan usaha yang dapat berpartisipasi dalam program Manajemen Berbasis Sekolah, penyelenggara pendidikan nonpemerintah, dan sebagainya.18

Keluarga dan masyarakat bukan lagi pihak yang pasif hanya penerima keputusan-keputusan dalam penyelenggaraan pendidikan. Mereka harus aktif menentukan dan membuat program bersama sekolah dan pemerintah. Oleh karena itu reformasi pendidikan harus sampai pada hubungan antara sekolah dengan keluarga dan sekolah dengan masyarakat dengan cara melibatkan secara aktif dalam kegiatan-kegiatan sekolah baik yang terkait langsung dengan kegiatan pembelajaran maupun non intruksional. Terdapat dua jenis pendekatan untuk mengajak orang tua dan masyarakat berpartisipasi aktif dalam pendidikan. Pertama, pendekatan scool-based dengan cara mengajak orang tua siswa datang ke sekolah melalui pertemuanpertemuan, konferensi, diskusi guru-orang tua, dan mengunjungi anaknya saat sedang belajar disekolah. Kedua, orang tua membantu

18 Imron, Ali. Kebijaksanaan Pendidikan Di Indonesia. Jakarta: Bumi Aksara, 2002 
anaknya belajar dirumah bersama dengan guru yang berkunjung ke rumah (home-based).19

a. Peran Serta Masyarakat dalam Dana dan Daya Pendidikan

Ada bermacam-macam tingkatan peran serta masyarakat dalam pembangunan pendidikan. Peran serta tersebut dapat diklasifikasikan dalam 7 tingkatan, yang dimulai dari tingkat terendah ke tingkat tertinggi. Tingkatan tersebut terinci sebagai berikut:

1) Peran serta dengan menggunakan jasa yang tersedia. Jenis PSM ini merupakan jenis paling umum. Masyarakat hanya memanfaatkan jasa sekolah dengan memasukkan anak ke sekolah;

2) Peran serta dengan memberikan kontribusi dana, bahan, dan tenaga. Masyarakat berpartisipasi dalam perawatan dan pembangunan fisik sekolah dengan menyumbangkan dana, barang dan atau tenaga;

3) Peran serta secara pasif. Artinya menyetujui dan menerima apa yang diputuskan oleh sekolah (komite sekolah), misalnya komite sekolah memutuskan agar orang tua membayar iuran bagi anaknya yang bersekolah dan orangtua menerima keputusan tersebut dengan mematuhinya

4) Peran serta melalui adanya konsultasi. Orangtua datang ke sekolah untuk berkonsultasi tentang masalah pembelajaran yang dialami anaknya;

5) Peran serta dalam pelayanan. Orang tua/masyarakat terlibat dalam kegiatan sekolah, misalnya orangtua ikut membantu

19 Prawirosentono, Suryadi, 2002. Filosofi Baru Tentang Manajemen Mutu Terpadu. Jakarta: PT. Bumi Reksa, Semarang 
sekolah ketika ada studi banding, kegiatan pramuka, kegiatan keagamaan, dan lain sebagainya

6) Peran serta sebagai pelaksana kegiatan yang didelegasikan/dilimpahkan. Misalnya, sekolah meminta orangtua/masyarakat untuk memberikan penyuluhan tentang pentingnya pendidikan, masalah gender, gizi dan lain sebagainya.

7) Peran serta dalam pengambilan keputusan. orangtua/masyarakat terlibat dalam pembahasan masalah pendidikan (baik akademis maupun non akademis) dan ikut dalam proses pengambilan keputusan dalam rencana pengembangan sekolah.

Dalam Peraturan Pemerintah No. 39 Tahun 1992 BAB III pasal 4 peran serta / partisipasi maysarakat dapat berbentuk:

1) Pendirian dan penyelenggaraan satuan pendidikan pada jalur pendidikan sekolah atau jalur pendidikan luar sekolah, pada semua jenis pendidikan kecuali pendidikan kedinasan, dan pada semua jenjang pendidikan di jalur pendidikan sekolah;

2) Pengadaan dan pemberian bantuan tenaga kependidikan untuk melaksanakan atau membantu melaksanakan pengajaran, pembimbingan dan/atau pelatihan peserta didik

3) Pengadaan dan pemberian bantuan tenaga ahli untuk membantu pelaksanaan kegiatan belajar-mengajar dan/atau penelitian dan pengembangan

4) Pengadaan dan/atau penyelenggaraan program pendidikan yang belum diadakan dan/atau diselenggarakan oleh Pemerintah untuk menunjang pendidikan nasional 
5) Pengadaan dana dan pemberian bantuan yang dapat berupa wakaf, hibah, sumbangan, pinjaman, beasiswa, dan bentuk lain yang sejenis;

6) Pengadaan dan pemberian bantuan ruangan, gedung, dan tanah untuk melaksanakan kegiatan belajar-mengajar

7) Pengadaan dan pemberian bantuan buku pelajaran dan peralatan pendidikan untuk melaksanakan kegiatan belajarmengajar;

8) Pemberian kesempatan untuk magang dan/atau latihan kerja

9) Pemberian bantuan manajemen bagi penyelenggaraan satuan pendidikan dan pengembangan pendidikan nasional;

10) Pemberian pemikiran dan pertimbangan berkenaan dengan penentuan kebijaksanaan dan/atau penyelenggaraan pengembangan pendidikan

11) Pemberian bantuan dan kerjasama dalam kegiatan penelitian dan pengembangan; dan

12) Keikutsertaan dalam program pendidikan dan/atau penelitian yang diselenggarakan oleh Pemerintah di dalam dan/atau di luar negeri. 20

Resbin L. Sihite; mengemukakan tujuh peran serta masyarakat dalam pendidikan yaitu:

1) Sebagai sumber pendidikan

2) Sebagai pelaku pendidikan

20 Suwarno, 1992. Pengantar Umum Pendidikan. Surabaya.: IKIP. UndangUndang Sisdiknas Republik Indonesia. 2003. No 20 Tahun 2003 Tentang Sistem Pendidikan Nasional. Jakarta : CV Triasco 
3) Pelaksana pendidikan

4) Pengguna hasil pendidikan

5) Perencanaan pendidikan

6) Pengawasan pendidikan

7) Evaluasi program pendidikan.

Sedangkan Tirtarahardja mengemukakan kaitan antara masyarakat dan pendidikan dapat ditinjau dari tiga segi, yaitu :

1) Mempunyai masyarakat sebagai penyelenggara pendidikan

2) Peran dan fungsi edukatif, dan

3) Masyarakat sebagai sumber belajar.21

Secara terinci manfaat hubungan lembaga pendidikan dengan masyarakat adalah sebagai berikut;

21 Hery Noer Aly dan Munzier Suparta, 2003.Pendidikan Islam Kini Dan Mendatang. Jakarta: CV. Triasco. 
Tabel 2. Manfaat Hubungan Lembaga Pendidikan

\begin{tabular}{|c|c|c|}
\hline & Bagi Lembaga Pendidikan & Bagi Masyarakat \\
\hline 1. & $\begin{array}{l}\text { Memperbesar dorongan } \\
\text { wawasan diri. }\end{array}$ & $\begin{array}{l}\text { 1. Tahu hal-hal persekolahan } \\
\text { dan inovasinva }\end{array}$ \\
\hline 2. & $\begin{array}{l}\text { Memudahkan memperbaiki } \\
\text { pendidikan }\end{array}$ & $\begin{array}{l}\text { 2. Kebutuhan-kebutuhan } \\
\text { masyarakat tentang }\end{array}$ \\
\hline 3. & $\begin{array}{l}\text { Memperbesar usaha } \\
\text { meningkatkan profesi pengajar. }\end{array}$ & $\begin{array}{l}\text { pendidikan lebih mudah } \\
\text { diwujudkan. }\end{array}$ \\
\hline 4. & $\begin{array}{l}\text { Konsep masyarakat tentang } \\
\text { guru/dosen menjadi benar. }\end{array}$ & $\begin{array}{l}\text { 3. Menyalurkan kebutuhan } \\
\text { berpartisipasi dalam }\end{array}$ \\
\hline 5. & Mendapat koreksi dari & pendidikan. \\
\hline & kelompok masyarakat. & 4. Melakukan usul-usul \\
\hline 6. & $\begin{array}{l}\text { Mendapat dukungan moral dari } \\
\text { masyarakat. }\end{array}$ & $\begin{array}{l}\text { terhadap lembaga } \\
\text { pendidikan. }\end{array}$ \\
\hline 7. & $\begin{array}{l}\text { Memudahkan meminta bntuan } \\
\text { dari masyarakat. }\end{array}$ & \\
\hline 8. & $\begin{array}{l}\text { Memudahkan pemakaian media } \\
\text { pendidikan masyarakat. }\end{array}$ & \\
\hline 9. & $\begin{array}{l}\text { Memudahkan pemanfaatan } \\
\text { narasumber. }\end{array}$ & \\
\hline
\end{tabular}

Seperti sudah diuraikan diatas, sekolah memanfaatkan hubungan dengan masyarakat sebagai mempertahankan hidupnya dan sebagian untuk melayani masyarakat. Faktor-fktor pendukung ini dapat diperoleh kalau manajer pendidikan mampu mengadakan komunikasi dan kerja sama yang baik dengan masyarakat. Dan untuk mengikutsertakan masyarakat dalam pendidikan sekolah melalui tokoh masyarakat yang aktif agar dalam pertemuan mereka dapat mengadu pendapat, bertukar pikiran, untuk menemukan alternatif peningkatan pendidikan, keputusan diambil secara musyawarah untuk memperoleh alternatif yang baik. 
"Sekolah yang hebat, karena siswanya hebat. Siswanya hebat karena gurunya hebat. Gurunya hebat karena kepala sekolahnya hebat". Itulah sebuah kalimat menarik dalam buku ini. Menjadikan siswa hebat, rahasianya adalah guru dan kepala sekolah memberikan keteladanan yang hebat. Buku yang berjudul "Sekolah Cinta" ibarat minum seteguk air, ditengah kehausan diterik matahari. Hadir di saat yang tepat adanya hiruk pikuk permasalahan pendidikan saat ini. Misalnya, masih ingat dalam benak kita, kasus kekerasan pemukulan seorang siswa terhadap guru di Madura sampai meninggal dunia. Dan Sekolah disibukan persoalan pelaksanaan Ujian Sekolah Berbasis Nasional (USBN), maupun Ujian Nasional (UN) yang hanya orientasi akademis semata.

Buku ini memaparkan sebuah konsep pendidikan modern. Sekolah yang atmosfernya penuh keteraturan, penuh keakraban satu sama lain, penuh antusiah belajar, semangar menebar prestasi, dan siap mengarungi tantangan untuk mengantarkan para siswanya sukses berlandaskan karakter yang diandalkan. Sehingga menjadikan Sekolah Islam Athirah yang luar biasa majunya di wilayah Sulawesi Selatan. Sekolah yang menjadi rujukan studi banding atas segudang prestasi yang diraih dan berhasil dalam manajemen sebuah sekolah. Apa rahasianya prestasi Athirah yang sekarang melambung tinggi di Indonesia Timur?

Jika siswa, guru, kepala sekolah rajin membaca, maka dipastikan cakrawala luas. Orang yang memiliki cakrawala luas, pasti berbanding lurus dengan kecakapan memandang persoalan, dan kecapakan mengurai persoalan. Membaca bisa menginspirasi untuk menyelesaikan persoalan. Membaca tak hanya sebatas jargon di 
Athirah, tetapi diwujudkan dalam gerakan nyata untuk merubah mindset seluruh komponen sekolah. Karena mindset seseorang sangat menentukan langkah dalam kehidupan.

Menurut Adi W Gunawan penulis buku ,"The Scret Of mindset "(2008:4), dijelaskan bahwa Mindset adalah cara berpikir yang mempengaruhi perilaku, dan sikap seseorang yang pada akhirnya menentukan keberhasilan seseorang.(hal;22). Oleh karena itu, untuk merubah mindset semua civitas sekolah di Athirah, setiap hari wajib membaca buku sastra. Sebagai gongnya dibuat semacam forum publik untuk menampilkan karya sastra siswa, guru maupun kepala sekolah.Selain itu ada gerakan resensi buku satu bulan sekali, kerjasama dengan wali murid untuk membelikan karya Satra Islami yang ditulis oleh tokoh atau ulama besar Islam. Setiap hari siswa selalu bersinggungan dengan karya sastra, menjadi sebuah pencerahan dan perubahan mindset sebagai energi solusi dalam menjalani hidup seseorang.

Gerakan seperti itu harus dimulai dari diri sendiri, bukan orang lain. Pak Edi Sutarto menjadi teladan agar diikuti seluruh anak buahnya dan siswanya. Beliau juga punya prinsip sebagaimana Qs.ArRadu;11. “ ... sesungguhnya Allah tidak akan merubah suatu kaum, sebelum mereka mengubah dirinya sendiri,". Agar seluruh elemen gemar membaca, butuh keteladanan oleh sosok pemimpin, dan itu menjadi kunci keberhasilan di Sekolah Athirah. Direktur memberikan contoh kepala sekolah. Kepala sekolah memberikan contoh gurunya. Gurunya memberikan contoh siswanya. Tentu masih banyak program di Sekolah Athirah yang dipaparkan dalam buku ini. yang bisa diadopsi oleh lembaga pendidikan lainnya. Pendidikan tak sekedar 
mengisi pengetahuan, tetapi bagaimana memotivasi siswa untuk menjadi manusia pembelajar sepanjang hayat melalui membaca.

Hidup yang membutuhkan kemampuan critical thinking, creativity, collaboration, dan communication. Agar empat kemampuan di miliki siswa, maka di perlukan sosok pendidik tak sekedar memiliki kompetensi dibidangnya, namun juga memiliki rasa cinta, percaya, dan optimisme tak bersyarat pada siswanya. Sebuah kisah guru dan karyawan non guru mencintai pekerjaanya, siswa mencintai belajar, para pemimpin sekolah mencintai amanahnya semuanya dikisahkan dalam buku ini. 


\section{Bab III \\ Tantangan Mencetak Generasi Islami}

\section{A. Mendidik Generasi Aqil Baligh}

Dua hari ini viral dalam dunia perwhatshapan alias WA. Berita duka seorang guru yang meninggal akibat ulah seorang siswa. Tepatnya Alm. Ahmad Budi Cahyono, guru GTT mapel Seni Rupa di SMA Negeri 1 Torjun-Sampang, sedangkan Siswa yang menganiaya bernama Moh. Holily, Siswa kelas XI SMA N 1 Torjun-Sampang. Sedih rasanya membaca berita itu, turut bela sungkawa atas kejadianya ini. Semoga Allah mengampuni segala dosanya,dan menerima segala amal baiknya serta keluarga yang ditinggalkan diberikan kesabaran. Aamiin ...

Tugas guru sangatlah berat yakni mendidik anak agar memiliki akal budi yang mulia, nyawa menjadi taruhannya. Terkadang niat baik itu justru mendapat balasan yang kurang baik dari seorang siswa bahkan dari wali murid. Jika ada ucapan yang menyakitkan, tindakan kurang menyenangkan dari seorang guru, itu diniatkan untuk merubah prilaku siswa menjadi lebih baik. Dalam hatinya, saya yakin tidak memiliki niat untuk menyakiti siswanya. Walau begitu berat tugas guru, yakinlah bahwa amal jairiah kebaikan seorang guru tak pernah berhenti dan kita petik di surga nanti.

Bagaimana sosok siswa tersebut? Berbagai sumber menyebutkan, siswa tersebut memiliki banyak catatan 'khusus' tentang ulahnya di sekolah. Banyak pendapat dari nitizen, semestinya ada perlakuan secara khusus oleh pihak sekolah agar tindakannya tidak menjadi-jadi. Butuh kerjasama antara sekolah 
dengan orang tua. Tetapi ibarat nasi sudah menjadi bubur. Pak budi sudah tiada, dari siswa kehilangan akal budinya. Yang seharusnya siswa menghormati gurunya, tetapi yang terjadi justru membunuhnya.

Siswa yang diduga sebagai pelakunya dijerat UU No. 11 tahun 2012 tentang sistem Peradilan Pidana Anak. Menurut aturan itu anak tersebut mendapat perlakukan khusus karena masih tergolong dibawah umur. Inilah menarik perlu kita kaji. Menurut aturan itu dikatakan dewasa itu usia tujuh belas tahun keatas dan belum menikah. Berarti Usia 0-17 tahun masih dianggap anak-anak belum dewasa. Padahal siswa itu perilakunya melebihi orang dewasa (berbuat kriminial). Hal ini menjadi persoalan jika dilihat dari segi psikologi hukum. Seharusnya ukuran dewasa dalam undang-undang diatas perlu diuji review dengan pertimbangan perkembangan anak usia sekarang. Benarkah anak sekolah menegah atas (SMA) belum dewasa?

Saya teringat pendapatnya ustad Andriano Rusfi psikoloq Universitas Indonesia (UI) bahwa Dalam konsep Islam, dikatakan dewasa itu sudah aqil baliqh. Artinya sampainya usia seseorang pada tahap kedewasaan yang dianggap mampu membedakan mana yang baik dan mana yang buruk. Dikatakan aqil baligh ditandai mimpi basah, usia sekitar lima belas tahun keatas bagi laki-laki. Dan sembilan tahun bagi perempuan yang ditandai mentruasi. Diusia itu sebenarnya sudah matang dalam bertanggungjawab terhadap diri sendiri termasuk mampu mencari nafkah sendiri. Jika ditarik pada zaman sahabat Rasulullah SAW. Banyak para pemuda saat itu 
memiliki aqidah yang kuat dan ikut berdagang membantu orang tuanya dewasa bahkan ikut berperang menegakkan agama.

Ustad Rusfi pernah menyampaikan bahwa Aqil berhubungan dengan akal dan baliqh terkait dengan hawa nafsunya. Fungsi Aqil (akal) untuk mengendlikan hawa nafsunya (baliqh). Beberapa kejadian anak dibawah umur melakukan perbuatan pidana. Bisa jadi dalam kasus diatas, sejatinya anak itu belum aqil, namun nalurinya sudah baligh. Inilah menjadi petaka bagi seseorang, ketika aqil dan baligh tidak hadir secara bersamaan. Akalnya tidak bisa mengendalikan apakah perbuatan baik atau buruk. Tetapi yang didahulukan adalah hawa nafsunya (baligh).

Berarti konsep aqil baligh mengalami pergeseran. Pada awalnya aqil baligh lahir secara bersamaan, tetapi realita baligh terkadang lebih dulu daripada aqil. Mengapa bisa terjadi demikian? Paling tidak disebabkan dua hal. Pertama, Pendidikan dalam keluarga tidak berjalan dengan baik. Ketidakhadiran sosok ayah dan ibu secara psikis terhadap perkembangan anak (aqil baligh). Seyogyanya secara konsep Islam usia diatas lima belas sudah mampu bertanggung jawab pada dirinya. Mindset orang tua sekarang ini, menyerahkan sepenuhnya pada sekolah terkait perkembangan anak. Tugas orang tua hanya mencari uang untuk membayar biaya anak. Padahal kasih sayang ayah dan ibu tak tergantikan. Sebenarnya sekolah hanya membantu orang tua dalam pendidikan anak. Sejatinya pendidikan keluarga adalah pendidikan pertama dan utama.

Kedua, lingkungan sekitar. Pergaulan teman sebaya sangat mempengaruhi prilaku dirinya. Jika pergaulanya baik insyallah prilakunya baik, sebaliknya pergaulan buruk pasti perilakunya buruk. 
Teman sangat menentukan masa depanya. Apalagi didukung perkembangan ilmu pengetahuan khususnya internet. Semua ada disitu baik atau buruk, tinggal manakah yang kuat, akal atau nafsunya. Hal ini menjadi tantangan kita sebagai orang tua maupun menjadi guru dalam mencetak generasi Aqil Baligh.

B. Urgensi Pengembangan Religiuos Culture Di Sekolah

Masyarakat Indonesia dikenal sebagai masyarakat yang berketuhanan (theocentris), artinya akar pembangunan dengan segala dimensinya selalu didasarkan pada nafas agama. Posisi strategis pendidikan agama dalam perspektif ke indonesiaan sesungguhnya merupakan perwujudan kongkret dari masyarakat Indonesia yang beragama22.

Adapun tujuan dari Pendidikan Agama Islam disekolah adalah 23:

1. Menumbuh kembangkan akidah melalui pemberian, pemupukan dan pengembangan pengetahuan, penghayatan, pengamalan, pembiasaan serta pengalaman peserta didik tentang agama Islam sehingga menjadi manusia muslim yang terus berkembang keimanan dan ketaqwaannya kepada Allah SWT.

2. Mewujutkan manusia Indonesia yang taat beragama dan berahklak mulia yaitu manusia yang berpengetahuan, rajin beribadah, cerdas, produktif, jujur, adil, etis, disiplin, toleran

22Mukhtar, Desain Pembelajaran Pendidikan Agama Islam (Jakarta: Misaka Galiza, 2003), 9.

23 PERMENDIKNAS N0.22 TAHUN 2006, Standar Isi Pendidikan Agama Islam Sekolah Menengah Atas (SMA), (Jakarta : Depag RI,2008),3-4. 
(tasamuh), menjaga keharmonisan secara personal dan sosial serta mengembangkan budaya agama "religious culture" dalam komunitas sekolah.

Hal ini sangat relevan dengan misi dan visi24 sekolah hampir semuanya adalah terwujudnya sekolah unggul berprestasi berdasarkan iman dan taqwa, berilmu pengetahuan luas, berbudi pekerti yang luhur, dan kreatif. Yang dijabarkan dengan misi antara lain sebagai berikut :

1. Menyelenggarakan pendidikan berwawasan global, berazazkan keimanan dan ketaqwaan terhadap Tuhan Yang Maha Esa.

2. Menyelenggarakan pembelajaran efektif dengan pendekatan multimedia pembelajaran

3. Mengembangkan kultur sekolah yang kondusif sehingga tercipta akhlak mulia dan penguasaan ilmu pengetahuan, bahasa, teknologi, olahraga, seni, budi pekerti luhur.

Namun realitas sosial yang ada di masyarakat, banyak sekali ditemui dalam sekolah maupun masyarakat prilaku prilaku menyimpang antara lain: negara kita termasuk salah satu negara yang tinggi tingkat korupsinya didunia, masalah kejujuran menjadi hal yang sangat langka, kejahatan kolektif dalam ujian, tindak kekerasan, kriminalitas, penyalah gunaan obat terlarang, pergaulan bebas, dan prilaku lain yang negatif, baik yang dilakukan pelajar maupun masyarakat umum. 
Pengertian pengembangan menurut Muhaimin dapat diartikan secara kualitatif dan kuantitatif yaitu bagaimana menjadikan pendidikan lebih meluas yang hanya tiga jam pelajaran itu dapat lebih meluas dan merata pengaruhnya baik di dalam maupun di luar sekolah. Kualitatif bagaimana menjadikan Pendidikan Agama Islam lebih baik bermutu, dan lebih maju sejalan dengan ide-ide dasar atau nilai-nilai Islam itu sendiri yang seharusnya selalu berada didepan dalam merespon dan mengantisipasi berbagai tantangan hidup dan kehidupan. Lebih lanjut dikatakan bahwa berpikir pengembangan mengajak seseorang untuk berpikir kreatif dan inovatif dalam melakukan perubahan (change) sebagai akibat dari kepribadian terhadap kondisi dan eksistensi pendidikan agama islam, yang diikuti dengan pertumbuhan (growth) dan pembaharuan atau perbaikan (reform) serta ditingkatkan secara terus menerus (continuity) untuk dibawa kearah yang lebih ideal.

Masalahnya sekarang adalah bagaimana supaya nilai nilai pendidikan agama yang dibekalkan kepada siswa tersebut dapat menghasilkan kemampuan intelektual atau ilmu pengetahuan dan tehnologi tinggi dengan tetap berbasis pada nilai keimanan, akhlak, psikologis, dan sosial yang tinggi pula, sehingga siswa mampu menghadapi berbagai macam persoalan (dilema) yang terus berkembang di masyarakat. Untuk mewujudkan tujuan pendidikan yang demikian tentu saja diperlukan wahana pembentukan dan proses yang memungkinkan anak didik berkembang menjadi manusia yang beriman dan bertaqwa serta berakhlak mulia melalui pengelolaan pendidikan agama secara formal dari pendidikan usia dini sampai pendidikan tinggi. 
Ironis memang kalau negara kita yang berdasarkan ketuhanan yang maha esa dalam prakteknya tidak tercermin hal tersebut, ( negara yang berdasarkan pada nilai Ketuhanan Yang Maha Esa), melihat kenyataan semacam itu ada seorang cendekiawan yang mengatakan bahwa pendidikan agama telah gagal, apa yang terjadi pada negara kita saat ini adalah buah dari pendidikan yang dianggap gagal. Penilaian bahwa pendidikan agama selama ini hanya membekali peserta didik dengan pengetahuan bersifat koqnitif atau bersifat tiori tidak pada pembentukan sikap dan pengalaman, yang dapat melahirkan amal amal sholeh. Dengan kata lain, pendidikan agama selain membelajarkan ibadah, juga diharapkan membangun moral siswa.25 Hal ini sesuai juga Indikasi dari kegagalan dengan diutusnya Rosulullah SAW untuk memperbaiki ahklah umat manusia. Oleh karena itu, pendidikan pada masa sekarang, menurut Muhaimin terutama Pendidikan Agama Islam pada dasarnya harus menyentuh tiga aspek26 yaitu :

1) knowing, yakni agar peserta didik dapat mengetahui dan memahami ajaran agama.

2) doing, yakni agar peserta didik dapat mempraktekkan /mengamalkan ajaran agama.

3) being, yakni agar peserta didik dapat menjalani hidup sesuai dengan ajaran agamanya.

25 Depag RI, Pendidikan Islam dan Pendidikan Nasional Paradigma Baru (Jakarta:Depag RI ,2005), 40.

26 Muhaimin , Rekontruksi Pendidikan Islam Dari Paradigm Pengembangan, Managemen Kelembagaan, Kurikulum Hingga Strategi Pembelajaran (Jakarta:Raja grafindo persada,2009),306. 
Idealnya ada tiga hal yang perlu di transfer melalui pendidikan tidak saja melakukan tranfer ilmu atau alih pengetahuan ( transfer of knowledge), alih ketrampilan (transfer of skill) dan alih nilai (transfer of value) seni termasuk didalamnya . Lebih jauh tugas Pendidikan Nasional adalah mengembangkan identitas peserta didik agar dia bangga menjadi bangsa Indonesia yang penuh dengan percaya diri memasuki kehidupan global sebagai seorang yang Indonesia yang berbudaya. Pendidikan memang bukan hanya bertujuan menghasilkan manusia pintar yang terdidik tetapi yang lebih penting ialah manusia yang terdidik dan berbudaya (educated and civilized human being) 27.

Kebudayaan dan pendidikan merupakan dua unsur yang tidak bisa dipisahkan karena saling mengikat28. Kebudayaan itu hidup dan berkembang karena proses pendidikan, sedangkan pendidkan itu sendiri hanya ada dalam kontek kebudayaan yang dinamik. Semua itu dapat diperoleh individu dengan interaksi dengan lingkungan, budaya, keluarga, dan masyarakat sekitar dan tentu saja sekolah sebagai lembaga pendidikan.

Kebudayaan itu dinamis dan terus berkembang karena adanya proses pendidikan. Proses pendidikan bukan hanya mentranformasikan nilai - nilai budaya tetapi juga mengembangkan dan bahkan dapat mematikan kebudayaan itu sendiri.29 Sebagai

27 H.A.R. Tilaar,Paradigma Baru Pendidikan Nasional (Jakarta :Rineka cipta, 2000), 209.

28 Budhisantoso, Pendidikan Sebagai Factor Dinamika Sosial (Jakarta:Depdikbud,2000), vii.

29 H.A.R. Tilaar, Pendidikan, Kebudayaan dan Masyarakat Madani Indonesia ( Bandung: Rosdakarya,1999), 167-182. 
proses tranformasi, pendidikan mentranformasikan nilai nilai dari suatu generasi kepada generasi lain. Disamping itu, pendidikan juga membentuk pribadi-pribadi yang kreatif yang menjadi penggerak serta pengembang dari jaringan kebudayaan dimana dia hidup30 pribadi yang tidak kreatif dan tidak produktif akan menjadi beban kebudayaan atau beban masyarakat, dengan demikian krisis kebudayaan adalah merupakan refleksi dari kegagalan sistem pendidikan.31

Dari apa yang penulis paparkan diatas maka menurut penulis terjadi paradog atau ketidak harmonisan antara pendidikan agama dengan budaya keagamaan. Oleh sebab itu, perlu pengembangan religious culture dalam dunia pendidikan khususnya di sekolah.

Adapun religious culture atau budaya agama yang penulis maksudkan adalah unsur budaya sekolah yang didasari nilai nilai agama terbentuk oleh tiga faktor yaitu:

1. keyakinan (the beliefs),

2. sikap (attitudes), dan

3. tingkah laku (behaviors), yang dianut oleh warga sekolah dalam kehidupan sehari-hari sebagi manifestasi nilai yang diyakini, dengan kata lain cara berpikir, bersikap, dan bertingkah laku yang sesuai dengan nilai nilai agama sebagai internalisasi dari nilai religious yang dianut warga sekolah.

30 Malik Fajar, Madrasah dan Tantangan Modernitas ( Bandung : Mizan ,1998), 16.

31 Tilaar, Paradigma Baru Pendidikan Nasional( Jakarta: Reneka cipta, $2000), 50$. 
Adapun bentuk pengembangan religious culture dengan kegiatan yang rutin seperti yang sudah dikembangkan di sekolah yaitu budaya pada ritual keagamaan, seperti

1. Sholat lima waktu dengan control absensi sholat.

2. Pelaksanaan kegiatan romadhon dalam satu bulan terstuktur.

3. Budaya $4 \mathrm{~S}$ senyum, sapa, salam dan santun, dalam kehidupan sehari-hari.

4. Infak jum'at sebgai bentuk peduli teman( uang infak disalurkan pada teman yang kurang mampu untuk membayar SPP)

5. Ikut berpartisipasi menjaga kebersihan kelas dan lingkungan sekolah dengan gerakan green and clean,

6. Membuang sampah pada tempatnya, mengurangi sampah dengan membawa tempat minum dan bekal dari rumah.

7. Datang ke sekolah tidak terlambat, mempunyai etos belajar yang tinggi.

8. Gemar membaca, sebagai upaya menaklukkan dunia.

9. Melakukan pembiasaan yaitu pada pembelajaran pendidikan agama islam siswa memulai dengan membaca ayat ayat suci AlQur'an dan resitasi hafalan ayat ayat pilihan.

10. Menutup aurat, memakai kerudung bagi siswa putri.

11. Memulai dan mengakhiri pelajaran dengan do'a yang terpusat dari kantor.

12. Sholat berjamaah dhuhur, dan membudayakan sholat dhuha.

13. Membudayakan puasa senin dan kamis.

14. Kultum atau kuliah tujuh menit yang dilakukan secara berkala setiap minggu sekali dengan hari yang berbeda. 
Adapun model pengembangan pendidikan agama kedepan agar religious culture tercapai dengan optimal menurut hemat penulis yaitu dengan pendidikan agama tidak saja dilakukan di dalam kelas tapi juga di luar kelas oleh seluruh warga sekolah, apresiasi yang tinggi terhadap semua warga sekolah yang ikut serta nenanamkan nilai nilai keagamaan pada semua warga sekolah karena selama kegiatan pendidikan apapun itu asalkan dinafasi dengan nilai nilai keagamaan, maka budaya religius yang diharapkan akan terwujud.

Tentunya dukungan dari semua pihak mulai dari kepala sekolah, komitmen para guru pendidikan agama islam dan dukungan semua guru, siswa serta semua komunitas sekolah, sarana prasarana dan sumber sumber belajar termasuk buku buku agama yang relevan akan sangat berpengaruh terdapat pencapaian religious culture yang kita harapkan.

Pembiasaan serta keteladanan dari guru sebagai ujung tombak pendidikan mampu menjadikan role model bagi siswa, akan sangat efektif seperti kata pepatah guru digugu dan di tiru. Sehingga budaya religius berlaku karena kesadaran nilai nilai yang diyakini yang akan melahirkan ketulusan bukan karena ancaman atau tekanan yang akan melahirkan kemunafikan.

Guru sebagai model berperan lebih dengan keteladanan yang diperankan, tidak hanya slogan tapi lebih pada tindakan dan uswatun hasanah seperti pada kata bijak guru kencing berdiri, murid kencing berlari. Apapun yang dilakukan oleh guru akan dijadikan patokan atau pedoman oleh peserta didik.

Hanya kultur sekolah yang baik (dinafasi nilai agama) akan menjadi soft skill dalam menggali potensi diri siswa. Indikator yang 
bisa dilihat pada keyakinan, sosialisasi, harapan yang tinggi, kebersamaan, ritual, nilai yang diyakini, artifak atau simbol simbul keagamaan dan saling mendukung, jiwa kepemimpinan, taggung jawab, sehingga langkah berikutnya menjadi pengembangan kurikulum khususnya hidden curriculum dan pada akhirnya akan terwujud learning community, karena masyarakat sekolah mendukung terjadinya sukses anak.

\section{Anak Curang, Salah Gurukah...?}

Hari itu tidak sengaja saya merubah cannel TV ada film menarik yang perlu kita simak. Flim itu berjudul CJ7. Walaupun saya tidak menonton secara utuh mulai awal, tapi ada pesan yang menarik yang perlu kita refleksikan dalam hidup kita. Dalam film itu ada yang seseorang ayah yang bekerja disuatu perusahaan. Tiap hari sang ayah sering marah-marah pada anaknya, karena anaknya mendapatkan nilai nol setiap kali ujian. Anak itu kemudian bereaksi tidak senang dengan ayahnya dan merasa takut jika mendapatkan nilai jelek lagi. Kepercayaan diri mulai hilang. Sutau ketika ujian akhir berlangsung anak ini mendapatkan nilai nol lagi, dengan perasaan takut dimarahi atau dihukum oleh ayahnya. Maka anak tersebut menggantinya dengan nilai seratus.

Ketika nilai ini diberitahukan kepada ayahnya, perasaan ayah luar biasa, senang, bangga. Kata ayahnya," baru kali ini nak kamu mendapatkan nilai bagus, bapak bangga". Sangat bangganya, anaknya mendapatkan nilai bagus dia tunjukkan pada teman-teman 
kerja diperusahaan, dan dibuktikan dengan selembar kertas hasil ujian.

Namun ketika Sang ayah ini menunjukan kepada direktur perusahaanya. Pak direktur melihat dengan cermat hasil ujian tersebut, dia mengatakan bahwa," anakmu telah berbuat curang, sebenarnya anakmu mendapatkan nilai nol tapi dirubah menjadi seratus,". Sang ayah ini tak terima dibilang anaknya curang. Sang ayah membalas dengan ucapan bahwa anak pak direktur yang curang. Sampai terjadi pertengkaran yang hebat.

Karena penasaran, dirumah Sang ayah bertanya pada anaknya," nak apa betul nilai ujian itu hasil curang, pertama anak tersebut mengelak bahwa hasil ujian itu merupakan kerja keras sendiri. Namun sang ayah tidak percaya, akhirnya anak itu mengaku kalau hasil itu curang. Alasan yang disampaikan karena ayah sering marah-marah, takut dihukum saya dan ayah menekan bahwa saya harus mendapatkan nilai bagus, maka perbuatan curang itu saya lakukan,"kata si anak itu.

Sang ayah ini sadar bahwa kecurangan anak tidak serta merta kesalahan anak itu sendiri, tetapi akibat sikap dan prilaku sang ayah. Dengan kejadian itu, terjadi perubahan sikap sang ayah, biasanya marah-marah berubah menjadi lebih perhatian dirumah, membimbing untuk belajar menjadikan anak semangat untuk belajar. Ketika menghadapi ujian anak tersebut betul-betul luar biasa perkembangan belajarnya. Guru-guru dikelas pada kaget tentang perubahan sikap saat dikelas, menjadi anak aktif dan cerdas. Biasanya mengikuti ujian sering tidak lulus, tetapi hari itu hasil ujian memuaskan dan dinyatakan lulus. Luar biasa.... 
Dari cuplikan cerita diatas, banyak hal yang perlu kita ambil pelajaran bagi orang tua atau guru yang sebentar lagi menghadapi penilaian akhir semester (PAS). Pertama, perbuatan marah-marah ketika anak mendapatkan nilai jelek, menjadikan perkembangan otak anak kurang berkembang. Ada suatu teori, jika seorang anak sering mendapatkan ucapan atau sikap yang negatif, kecenderungan prilaku dan sikapnya negatif. Sebaliknya, jika anak sering mendapatkan ucapan atau kalimat positif yang memotivasi maka kecenderungan sikapnya positif. Sebaiknya kita sebagai orang tua atau guru lebih mengevaluasi mengapa anak saya mendapatkan nilai jelek?apakah waktu belajarnya kurang?ataukah perhatihan kita terhadap anak kurang?ataukah cara mengajar kita belum mengetahui kebutuhan anak? dari evaluasi tersebut baru kita mengetahui masalah yang terjadi pada anak, terus kemudian mengambil langkah untuk mencari solusinya.

Kedua, Sering kali orang tua menuntut atau menekan kepada anak untuk mendapatkan nilai tertinggi atau mendapatkan rangking dikelas. Kita harus sadar bahwa kemampuan anak itu berbeda-beda dan potensi anak itu tidak sama dengan teman yang lainya. Mungkin pada saat ujian nilai mata pelajaran tertentu jelek, tetapi pada sisi lain mungkin juga pada mata pelajaran lain nilainya bagus. Kita harus yakin bahwa Allah menciptakan manusia sangat unik dan dibekali pontesi yang kadang kita tidak tahu. Lebih baik kita bersikap positif atau memotivasi kepada anak untuk mendapat nilai lebih baik dari sebelumnya. Dan membatu untuk menemukan potensi yang dimiliki seorang anak, jika sudah mengetahui potensi yang dimilikinya maka kesuksesan akan diraihnya. 
Ketiga, Seorang anak yang mendapatkan perhatian dan bimbingan setiap belajar akan menjadikan anak merasa percaya diri pada kemampuannya. Termotivasi untuk belajar dan belajar yang akhirnya akan mencapai hasil yang memuaskan.

Keempat, Kita sering kali menuntut hasil pada anak, bukan pada prosesnya. Padahal hasil yang dicapai anak belum tentu dengan proses yang jujur dan cara yang benar. Anak mendapatkan nilai yang bagus tetapi dengan cara yang curang, ini sangat berbahaya jika dewasa nanti, ia akan mengambil jalan pintas. lebih baik mendapatkan nilai jelek dengan proses yang jujur, betul-betul kerja keras sendiri. Akan lebih baik lagi jika mendapatkan nilai yang bagus dengan proses yang baik pula.

Kita lebih utamakan adalah prosesnya bukan hasil. Jika prosesnya baik, lambat laun kebaikan akan tercapai, dan insyaallah hasilnya pun akan memuaskan. Jika anak mengalami kegagalan, maka ini harus dijadikan motivasi untuk mencapai keberhasilan. Kegagalan adalah langkah awal untuk mencapai kesuksesan.

Tentu kita semua mengharapkan anak-anak kita mendapatkan nilai optimal, dan memiliki ilmu yang bermanfaat dan berakhkul karimah, bukan terletak pada nilai yang tertulis pada rapor semata. Percuma jika nilai rapor bagus tetapi tidak mengetahui ilmunya. Apalagi sikap dan perlakunya tidak menunjukan berakhkulkarimah, sangat mensengsarakan dirinya dan membuat malu orang tua dan guru pada akhirnya. Naudzubillah........

D. UNBK Jujur dan Berintegritas 
Besok senin, satu April 2019 mulai Ujian Nasional Berbasis Komputer (UNBK) jenjang SMA. Semoga tahun ini UNBK berjalan dengan penuh kejujuran dan berintegritas. Karena tahun lalu, tidak luput dari tindak kecurangan diberbagai daerah.

Di Surabaya misalnya, tereka dalam memori kita tahun lalu terjadi kecurangan yang dilakukan oleh oknum kepala sekolah SMA Negeri di Surabaya, berujung pada proses hukum. Kejadian itu menjadi berita nasional. Yang telah mencoreng nama baik kota Pahlawan.

Berdasarkan berbagai informasi, kecurangan pada UNBK tahun lalu ada beberapa modus. Pertama, ada seorang siswa dengan sengaja memfoto soal melalui handphone (HP), kemudian dikirim lewat Whatshaap (WA) pada guru bimbingan belajarnya. Hal ini terjadi akibat kelonggaran pengawas untuk membiarkan siswa membawa HP. Kedua, kecurangan dilakukan oleh kepala sekolah bekerjasama dengan guru untuk membobol soal UNBK dengan memasang jaringan diruang tertentu. Sehingga dengan leluasa mendapatkan soal dan dikerjakan oleh oknum guru, lalu kunci disebarkan ke siswa.

Lalu pertanyaan muncul mengapa mereka melakukan kecurangan? Padahal UNBK tidak lagi menjadi penentu kelulusan, hanya sekedar pemetaan pendidikan. Ada beberapa kemungkinan. Pertama, tuntutan dari orang tua untuk mematok nilai UNBK tinggi. Karena nilai UNBK masih dijadikan ukuran untuk masuk pada jenjang berikutnya khusunya sekolah negeri terbaik. Sehingga siswa menggunakan segala cara ingin mendapatkan nilai terbaik agar masuk sekolah unggulan. 
Kedua, kurang siapnya sekolah dalam memberikan bekal pada siswa dalam menghadapi UNBK. Sehingga seorang siswa berupaya semaksimal mengejar hasil tinggi dengan cara curang. Ketiga, hasil UNBK menjadi prestise nama baik sekolah. Jika hasil UNBK tidak baik, bisa jadi kualitas sekolah kurang baik. Dan tidak menutup kemungkinan kepala sekolah dimutasi. Sehingga semua komponen sekolah membentuk 'tim sukses' dengan cara tidak dibenarkan.

Melihat modus dan motif kecurangan seperti itu, agar UNBK tahun ini jujur dan terintegritas, maka diperlukan beberapa langkah. Pertama, memperketat standart operasi pelaksanaan (SOP) UNBK 2019 pada level teknis. Dan bekerjasama dengan perguruan tinggi yang memiliki ahli teknologi, agar membuat sistem soal UNBK tidak mudah dibobol lagi. serta mempertegas pada semua pengawas atau pihak sekolah, jika melakukan tindakan kecurangan akan berurusan dengan hukum.

Kedua, penanaman nilai kejujuran pada siswa, guru, kepala sekolah dan orang tua. Perlu sekiranya dimasukan dalam bawah sadar pada semua komponen pendidikan, bahwa kejujuran suatu hal yang sangat penting dalam kehidupan. Berbuat tidak jujur di sekolah, sama halnya ikut berkontribusi menabur benih kehancuran bangsa ini. Sebagaimana pendapat Thomas Lickona dari Cortland University (1992) mensinyalir tanda-tanda kehancuran suatu bangsa, antara lain yaitu adanya praktik ketidakjujuran yang membudaya.

Ketiga, memperbaiki proses pembelajaran. Kita semuanya harus sepakat bahwa dalam pendidikan harus mengutamakan proses daripada hasil. Dengan Memperbaiki proses pembelajaran dengan 
baik, akan mendapatkan hasil yang baik. Misalnya dengan mempersiapkan jauh-jauh hari dengan bimbingan belajar intensif di sekolah. Yang didalamnya ada program try out, pembahasan dan motivasi. Agar siswa-siswi kita siap mengikuti UNBK, bukan memiliki mental penerabas meminjam istilah Koentjoroningrat. Mental penerabas bisa diartikan mengambil jalan pintas dalam mencapai tujuan, tanpa melalui proses. Inilah titik lemah dalam budaya bangsa Indonesia yang bisa merusak segala sendi kehidupan.

Keempat, memberikan pemahaman pada siswa, bahwa hasil UNBK memang penting menjadi salah satu indikator keberhasilan aspek pengetahuan, akan tetapi hasil UNBK bukan segala-galanya mencapai kesuksesan. Jika merujuk penelitian di Harvard University Amerika Serikat (Ali Ibrahim Akbar, 2000), ternyata kesuksesan seseorang tidak ditentukan semata-mata oleh pengetahuan dan kemampuan teknis (hard skill) saja. Akan tetapi lebih pada kemampuan mengelola diri dan orang lain (soft skill). Penelitian ini mengungkapkan, kesuksesan hanya ditentukan sekitar 20 persen oleh hard skill dan sisanya 80 persen oleh soft skill. Bahkan orangorang tersukses di dunia bisa berhasil dikarenakan lebih banyak didukung kemampuan soft skill daripada hard skill. Upaya mewujudkan pelaksanaan UNBK jujur dan berintegritas, menjadi tanggung jawab seluruh insan peduli pendidikan. Maka diperlukan komitmen bersama, tak cukup mentandatangi secara formalitas pakta integritas. Akan tetapi lebih diwujudkan secara konkrit dalam sikap dan tindakan jujur dan berintegritas. 
-oOo- 
Daftar Pustaka

Budhi Santoso, Pendidikan Sebagai Factor Dinamika SosiaL (Jakarta: Depdikbud, 2000)

Depag RI, Pendidikan Islam dan Pendidikan Nasional Paradigm Baru (Jakarta:Depag RI ,2005.

Mukhtar, Desain Pembelajaran Pendidikan Agama Islam (Jakarta: Misaka Galiza, 2003)

Muhaimin, Rekontruksi Pendidikan Islam Dari Paradigm Pengembangan, Managemen Kelembagaan, Kurikulum Hingga Strategi Pembelajaran (Jakarta:Raja grafindo persada, 2009)

H.A.R. Tilaar, Paradigma Baru Pendidikan Nasional (Jakarta :Rineka cipta, 2000).

H.A.R. Tilaar, Pendidikan, Kebudayaan dan Masyarakat Madani Indonesia (Bandung: Rosdakarya, 1999)

Asmani, Jamal Makmur. 2009. Tips Menjadi Guru Inspiratif, Kreatif dan Inofatif. Jakarta : Diva Press.

Dimyati dan Mujiono. 2002. Belajar dan Pembelajaran. Jakarta: Rineka Cipta

Hanafiah Nanang dan Nuur Suhada, Konsep Strategi Pembelajaran, (Bandung: Refika Aditama, 2009)

Huda, Miftahul, 2013, Model-model Pembelajaran dan Pengajaran, Pustaka Pelajar, Yoyakarta 
Mulyatiningsih, 2012, Pembelajaran inovatif, Sinar Baru, Bandung

Wina Sanjaya, strategi Pembelajaran berorientasi standar proses pendidikan, Jakarta Kencana Prenada Media, 2007

Wilis Dahar, Ratna, 2006, Teori - teori Belajar dan Pembelajaran, Bandung

-oOo- 